\title{
Effects of Cropping System and Cowpea Variety on Symbiotic Potential and Yields of Cowpea (Vigna unguiculata L. Walp) and Pearl Millet (Pennisetum glaucum L.) in the Sudano-Sahelian Zone of Mali
}

\author{
Zoumana Kouyaté,, Tatiana Krasova-Wade, ${ }^{2}$ Inamoud Ibny Yattara, ${ }^{3}$ and Marc Neyra ${ }^{2,4}$ \\ ${ }^{1}$ Institut d'Economie Rurale, P.O. Box 258, Rue Mohamed V, Bamako, Mali \\ ${ }^{2}$ UR040, Institut de Recherche Pour le Développement, Laboratoire Commun de Microbiologie IRD/ISRA/UCAD, \\ Centre de Recherche de Bel-Air, Route des Hydrocarbures, P.O. Box 18524, Dakar, Senegal \\ ${ }^{3}$ Faculté des Sciences et Techniques, Universite des Sciences Techniques et Technologies de Bamako, P.O. Box 3206, Bamako, Mali \\ ${ }^{4}$ Irstea, UR MALY, 69336 Lyon, France
}

Correspondence should be addressed to Zoumana Kouyaté, zkouyate@yahoo.fr

Received 26 April 2012; Revised 18 June 2012; Accepted 2 July 2012

Academic Editor: Robert J. Kremer

Copyright ( $\odot 2012$ Zoumana Kouyaté et al. This is an open access article distributed under the Creative Commons Attribution License, which permits unrestricted use, distribution, and reproduction in any medium, provided the original work is properly cited.

\begin{abstract}
Many cowpea varieties (Vigna unguiculata L. Walp) have been proposed by research in Mali. None of these varieties were investigated for their symbiotic potential in terms of root nodulation and mycorrhizal infection. An experiment was conducted at Cinzana Research Station, from 2007 to 2009 with an objective to identify a cowpea variety with high symbiotic potential which may improve millet/cowpea cropping global production. Randomized complete block (RCBD) design with a factorial combination of 3 cowpea varieties (IT89KD-374, CZ1-94-23-1, and CZ11-94-5C) and 2 cropping systems (millet/cowpea intercropping and cowpea-millet rotation) was used. On farm test was conducted to evaluate CZ11-94-5C and IT89KD-374 nodulation performance. Cowpea variety CZ11-94-5-C had the highest nodule number and nodule weight. Millet/cowpea alternate rows intercropping $(1 / 1)$, only, had a significant influence on cowpea root infection rates by mycorrhizae, on the 45th day after emergence. IT89KD374 gave the best cowpea grain yield $\left(1540 \mathrm{~kg} \mathrm{ha}^{-1}\right)$ in sole crop. The highest millet grain yield $\left(1650 \mathrm{~kg} \mathrm{ha}^{-1}\right)$ was obtained under CZ11-94-5C-millet rotation. Farmers' fields assessments results confirmed CZ11-94-5C performance on research station. The CZ11-94-5C cowpea variety needs to be more characterized.
\end{abstract}

\section{Introduction}

Cowpea (Vigna unguiculata L. Walp) is the main legume food crop in the Sudano-Sahelian zone of Mali [1]. It is one of the main pulses contributing to the economy of nitrogen in cropping systems with low input through the biological nitrogen fixation [2]. This symbiotic nitrogen fixation can reduce the rate of depletion of cultivated soils where legume-cereal rotation is practiced [3]. If cowpea is nodulated by powerful strains of Bradyrhizobia, $90 \%$ of the required nitrogen for maximum yield can derive from biological nitrogen fixation [4]. According to Peoples et al. [5] Dakora and Keya [6], the values of $\mathrm{N}$ contribution by various legumes, including Cowpea (Vigna unguiculata L. Walp), are important $\left(50\right.$ to $\left.300 \mathrm{~kg} \mathrm{~N} \mathrm{ha}^{-1} \mathrm{yr}^{-1}\right)$. These values depend on the legume plants density, the cropping system, and the legume genotype [7]. Venkateswarlu et al. [8] showed that cowpea Bradyrhizobia nodulating population density depends very significantly on the cultural practices rather than rainfall. So far, very little attention has been addressed to the agromicrobiological aspects in cowpea research in Mali. In order to fill this gap, the present study was conducted from 2007 to 2009 at Cinzana Agronomic Research Station in the SudanoSahelian zone of Mali. The objective was to compare the potential of root nodulation and mycorrhizal infection of three cowpea varieties in three cropping systems and to 


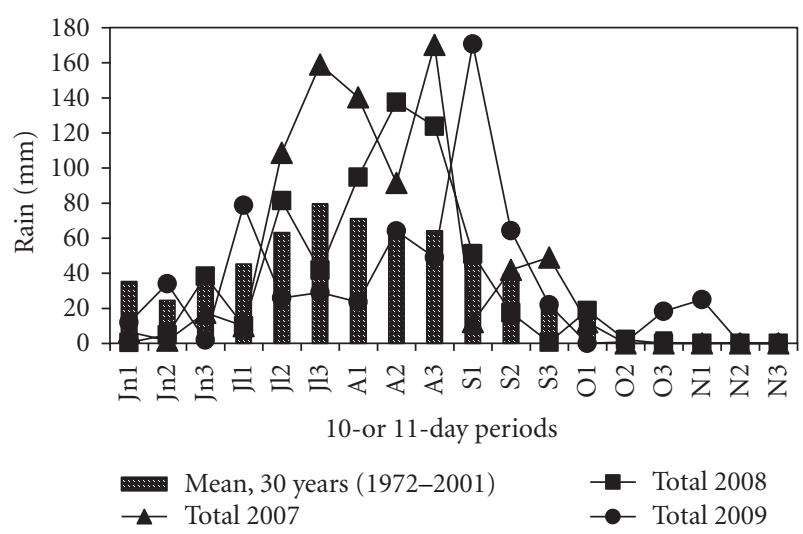

Figure 1: Rainfall in 10- or 11-day periods at Cinzana Agronomic Research Station (1972-2001), 2007, 2008, and 2009.

identify an efficient cropping system that can improve cowpea and millet yields.

\section{Materials and Methods}

2.1. Site Description. The research was conducted at the Cinzana Agronomic Research Station, SRAC $\left(13^{\circ} 15^{\prime} \mathrm{N}^{\circ} 5^{\circ}\right.$ $57^{\prime} \mathrm{W}$, altitude $281 \mathrm{~m}$ ). The Cinzana Station is located in the Rural Commune of Cinzana, at $5 \mathrm{~km}$ far from Cinzana village situated $45 \mathrm{~km}$ from Segou city on the way Segou-Mopti.

The climate is characterized by an interannual variability of rainfall, turbulent high intensity, and irregular intraseason rains. The rainy season begins in June-July and ends in September-October. More than half of the rain usually falls in July-August (Figure 1). Mean annual rainfall over a 30-year period (1972-2001) was $670 \mathrm{~mm}$. During the three years of experimentation (from 2007 to 2009), rainfall received at Cinzana Agronomic Research Station varied from $654 \mathrm{~mm}$ (2008) to $909 \mathrm{~mm}$ (2007).

2.1.1. Soil. The research was conducted on a leached tropical ferruginous soil with spots and concretions [9], a plinthaquic Haplustalf according to the American classification [10]. Composite soil samples were collected on the depths $0-20$, $20-40 \mathrm{~cm}$, and $40-60 \mathrm{~cm}$ before the establishment of the experiment to determine $\mathrm{N}, \mathrm{P}, \mathrm{K}$, soil organic carbon $\mathrm{C}, \mathrm{pH}$, and CEC. Soil organic carbon (SOC) content was measured by the Anne method. Mineralization was done using concentrated sulfuric acid $\left(\mathrm{H}_{2} \mathrm{SO}_{4}\right)$ with dichromate of potassium $\left(\mathrm{K}_{2} \mathrm{Cr}_{2} \mathrm{O}_{7}\right)$ and the solution was titrated with iron sulfate $\left(\mathrm{FeSO}_{4}\right)$. The $\mathrm{pH}$ was determined by the electrometric method in a soil solution with a soil/water ratio of $1 / 2.5$. Cation exchange capacity (CEC) and exchangeable bases $\left(\mathrm{Ca}^{2+}, \mathrm{Mg}^{+2}, \mathrm{~K}^{+}, \mathrm{Na}^{+}\right)$were determined by the method of ammonium acetate. The phosphorus was determined by the method Bray2 (solution of $\mathrm{HCl}+\mathrm{NH}_{4} \mathrm{~F}$ ). The texture is predominantly sandy in the first $40 \mathrm{~cm}$ layer of the soil. The upper horizon $(0-20 \mathrm{~cm})$ contains only $6 \%$ clay, content that is not favorable to the development and the maintenance of a good structure. It is chemically a very poor soil. The $\mathrm{pH}$ is very strongly acid (4.5) in the first $20 \mathrm{~cm}$ layer, extremely acid between 20 and $60 \mathrm{~cm}$ deep. It is very poor in organic matter $(\mathrm{OM}<0.6 \%)$ and deficient in available phosphorus $(P<$ $13 \mathrm{ppm}$ ) with a low reserve of total phosphorus.

2.1.2. Plant. The plant material used consisted of three (3) varieties of cowpea and one variety of pearl millet. The three cowpea varieties were IT89KD-374 (65-70 days) from IITA (International Institute of Tropical Agriculture), CZ1-94-231 (75-80 days), and CZ11-94-5C (65-70 days) from IER (Institut d'Economie Rurale), which is the National Agronomic Research Institute of Mali. These varieties are semiprostrate and semideterminate cowpea varieties. The variety of millet used was $\mathrm{NKO} \times$ Toroniou C1 (110 days) from IER.

\subsection{Methods}

2.2.1. Experimentation on Research Station. The experiment was conducted in two series (2007-2008; 2008-2009) based on a complete randomized blocks design, 4 replications. Treatments consisted of a factorial combination of 3 cropping systems and 3 cowpea varieties. The 3 cropping systems consisted of the millet/cowpea intercropping in alternate rows ( 1 row millet/ 1 row cowpea), the millet/cowpea intercropping in interhills ( 2 hills mil/1 hill cowpea) and cowpeamillet rotation.

The 3 cowpea varieties were IT89KD-374, CZ1-94-23-1, and CZ11-94-5C. Plot size was $7.5 \mathrm{~m} \times 8 \mathrm{~m}=60 \mathrm{~m}^{2}$. Soil was prepared by ridging to the tractor at $0.75 \mathrm{~m}$ spacing between ridges or 10 ridges of $8 \mathrm{~m}$ long. Seedings were made manually on the ridges. A dose of $300 \mathrm{~kg} \mathrm{ha}^{-1}$ Tilemsi natural rock phosphate (PNT) was applied in 2008 on all of the plots of the first experiment and at the beginning of the 2009 rainy season for the second.

Cowpea in monocropping system was sown on top of ridges by hand at $0.40 \mathrm{~m}$ between the hills or $0.75 \mathrm{~m} \times 0.40 \mathrm{~m}$ and thinned at two plants per hill after crop emergence ( 66 667 plants ha $\left.^{-1}\right)$. In the millet/cowpea intercropping alternating rows ( 1 millet/1 cowpea), the spacing of the cowpea seedlings was $0.40 \mathrm{~m}$ between the hills, or $1.50 \mathrm{~m} \times 0.40 \mathrm{~m}$ and thinned at two plants per hill after crop emergence (33 333 plants ha ${ }^{-1}$ ). In interhills system (2 hills millet/1 hill cowpea), cowpea was sown at $1.60 \mathrm{~m}$ between the hills of cowpea or $0.75 \mathrm{~m} \times 1.60 \mathrm{~m}$ and thinned to two plants per hill after crop emergence (16 667 plants ha $^{-1}$ ). The cowpea was sown to the lifting (raising) of millet in the interhills cropping system (2/1), while it was sown simultaneously with the millet in the alternating rows cropping system (1/1). Weedings were done manually as needed using hoe and mounded at the millet growth stage.

Crop symbiotic potential has been characterized through the study of cowpea nodulation and the assessment of the rate of mycorrhizal colonization of the roots of the two crops (millet and cowpea). Nodules harvesting was carefully done by digging up 2 hills of 2 plants in different basic plot points. All of the nodules collected were washed. The total number of nodules was evaluated by counting. The size of 
the nodules has been measured with a slide calipers and their efficiency estimated by dissection and observation of the presence of corresponding to leg hemoglobin coloration (reddish). Nodules weight dry was determined by weighing after drying in an oven at $65^{\circ} \mathrm{C}$.

Mycorrhizal roots were collected in the 45th day after emergence and flowering stage. They were washed in tap water to remove soil and dried in the shade. In the laboratory, roots were treated with $70 \%$ alcohol and then rinsed with tap water to eliminate alcohol. Then, were dipped in $10 \% \mathrm{KOH}$ at $80^{\circ} \mathrm{C}$ for $30 \mathrm{~min}$ followed by a bath Marie at $80^{\circ} \mathrm{C}$ for $10 \mathrm{~min}$ to eliminate the cytoplasmic contents of root cells to better reveal the mycorrhizal structures.

Mycorrhizal fungi were highlighted directly on root fragments after staining in a $0.05 \%$ Trypan blue solution for $30 \mathrm{~min}$ at $80^{\circ} \mathrm{C}$ and microscopy observation. Phillips and Hayman [11] method was used to estimate the natural mycorrhization rates.

2.2.2. Evaluation of Cowpea Nodulation and Its Impact on the Yield in Farmers' Fields. Assessments of the promising results obtained on station with CZ11-94-5C and IT89KD-374 cowpea varieties were conducted in farmers' fields in Cinzana Rural commune during the 2010 growing season. Eight villages of the municipality were chosen based on their accessibility (roadside). Farmers' choice was made on voluntary basis to conduct the test.

Two improved cowpea varieties CZ11-94-5C and IT89KD-374 and the local millet variety of the collaborating farmer were used. The two cowpea varieties are short maturity types (65-70 days) as previously.

The experimental design used was plots of observations in scattered replications. Each farmer had a block of complete treatments and therefore was a replication. Six (6) treatments were compared: sole crop of CZ11-94-5C (T1), sole crop of IT89KD-374 (T2), millet/CZ11-94-5C intercropping (1 row/1 row) (T3), millet/IT89KD-374 intercropping (1 row/1 row) (T4), millet/CZ11-94-5C intercropping (2 rows/1 row) (T5), millet/IT89KD-374 intercropping (2 rows/1 row) (T6). Plots size was $400 \mathrm{~m}^{2}(20 \mathrm{~m} \times 20 \mathrm{~m})$. Cowpea plots did not receive fertilizer. Mixtures of $50 \mathrm{~kg}$ DAP (diammonium phosphate) and $50 \mathrm{~kg} \mathrm{ha}^{-1}$ of urea were applied on the millet rows.

The test was conducted in nineteen farmers' fields. The objective was to evaluate at farmer's level the performance of nodulation and the two cowpea varieties (CZ11-94-5C and IT89KD-374) yields in three cropping systems.

The seedings have been carried out between July 25 and August 03, 2010.

\section{Results}

3.1. Experimentation on Research Station. The rainfall distribution graph (Figure 1) indicated more rain $(909 \mathrm{~mm})$ in 2007 than 2008 and 2009 (654 and $663 \mathrm{~mm}$, resp.). In 2007 and 2008, the monthly rainfall was above the 30 years' average while that of 2009 was much below. The year 2009 was particularly dry in June, July, and August and very wet

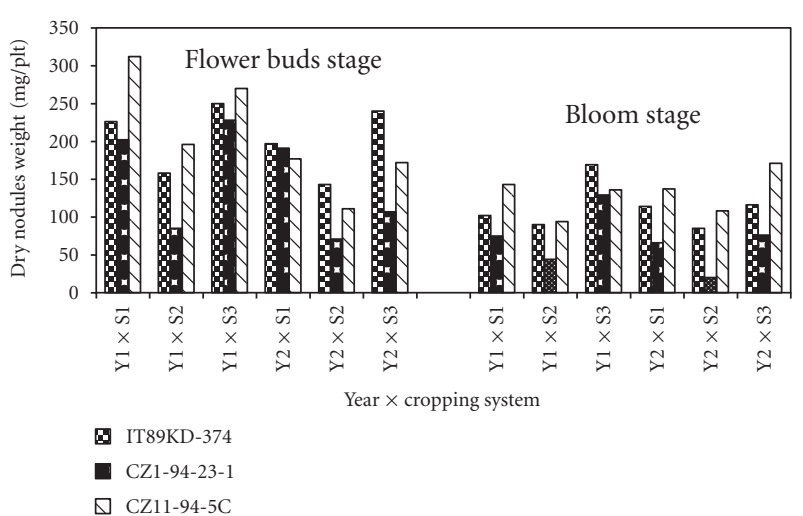

Figure 2: Nodules dry weight (mg/plant) as affected by year $\times$ cropping system $\times$ cowpea variety interactions effects $(P<0.01)$ at flower buds and bloom stage at Cinzana Agronomic Research Station, 2007 and 2008. Y1: year 1 (2007); Y2: year 2 (2008), S1: alternate rows intercropping (1 row millet/1 row cowpea), S2: inter hills intercropping (2 hills millet/1 hill cowpea), S3: cowpea sole crop, cowpea varieties: IT89KD-374, CZ1-94-23-1, and CZ11-94$5 \mathrm{C}$.

in September. In 2008, the last decade of July was dry. These distribution patterns certainly had some influence on crop growth habit and contributed to yield differences.

3.1.1. Cropping System Effects on the Number and Weight of Cowpea Nodules. At the flower buds stage, highly significant differences $(P<0.01)$ were observed between cropping systems effects on the nodules number by plant (Table 1 ). Alternate row intercropping ( 1 row millet/ 1 row cowpea) had higher nodule number than any other treatment. Concerning nodules dry weight, a three-way interaction $(P<0.01)$ occurred between factors at all stages (Figure 2). The CZ194-23-1 cowpea variety tended to have the lowest nodule weight in all systems while the CZ11-94-5C tended to have the highest. A similar effect was observed for nodules number at bloom stage (data not shown).

3.1.2. Nodules Efficiency. Cropping system effects on efficient nodule numbers $(P<0.05)$ indicated that at flower bud stage, sole cowpea crop and cowpea in alternated row intercropping had the highest numbers (Table 1). A slight decrease in the number of efficient nodules was observed between flower buds stage and blooming (data not shown) with a highly significant impact of the variety whatever the development stage is.

3.1.3. Cropping System Effects on Millet and Cowpea Mycorrhization. Average mycorrhization rates of cowpea and millet were at the same order of magnitude at flower buds (30-40\%) and flowering stages (40-50\%). Cropping systems and cowpea varieties did not have a significant influence $(P>$ 0.05 ) on mycorrhizal colonization rates, except the cowpea on the 45th day where differences were highly significant $(P<0.01)$ for the millet/cowpea alternate rows intercropping $(1 / 1)$. 
TABLE 1: Cowpea nodules number (nodules/plant) and efficiency as affected by cropping system and cowpea variety at flower buds stage at Cinzana Agronomic Research Station, 2007 and 2008.

\begin{tabular}{|c|c|c|}
\hline \multirow{2}{*}{ Treatments } & \multicolumn{2}{|c|}{ Flower buds stage } \\
\hline & Nodules number (nodules/plant) & Efficient nodules (\%) \\
\hline \multicolumn{3}{|l|}{ Years } \\
\hline Year 1: 2007 & $41^{\mathrm{a}}$ & 77 \\
\hline Year 2: 2008 & $30^{\mathrm{b}}$ & 76 \\
\hline \multicolumn{3}{|l|}{ Cropping systems } \\
\hline Millet/cowpea intercropping ( 1 row/1 row) & $47^{\mathrm{a}}$ & $78^{\mathrm{ab}}$ \\
\hline Millet/cowpea intercropping (2 hills/1 hill) & $19^{c}$ & $69^{\mathrm{b}}$ \\
\hline Cowpea sole crop & $40^{\mathrm{b}}$ & $81^{\mathrm{a}}$ \\
\hline \multicolumn{3}{|l|}{ Cowpea varieties } \\
\hline V1: IT89KD-374 & 36 & $86^{\mathrm{a}}$ \\
\hline V2: CZ1-94-23-1 & 32 & $62^{\mathrm{b}}$ \\
\hline V3: CZ11-94-5C & 37 & $80^{\mathrm{a}}$ \\
\hline Effect & $P$ values & $P$ values \\
\hline Year $(Y)$ & $<0.01$ & - \\
\hline Cropping system $(\mathrm{S})$ & $<0.01$ & 0.03 \\
\hline Year $\times$ cropping system $(\mathrm{Y} \times \mathrm{S})$ & 0.07 & - \\
\hline Cowpea variety $(\mathrm{V})$ & 0.06 & $<0.01$ \\
\hline Year $\times$ variety $(\mathrm{Y} \times \mathrm{V})$ & $<0.01$ & 0.30 \\
\hline Cropping system $\times$ cowpea variety $(S \times V)$ & - & - \\
\hline Year $\times$ cropping system $\times$ variety $(\mathrm{Y} \times \mathrm{S} \times \mathrm{V})$ & 0.13 & - \\
\hline Coefficient of variation $(\%)$ & 22.78 & 21.21 \\
\hline
\end{tabular}

Means followed by the same letters in the same column for each parameter are not significantly different $(P \leq 0.05)$, according to Duncan test.

3.1.4. Cropping System Effects on Cowpea Plants Density and Yield. The three-way interaction between year $\times$ cropping system $\times$ cowpea variety was highly significant (Figure 3 ). Cowpea sole crop was the best treatment whatever the year. The most important plants density was obtained with IT89KD-374 sole crop in year one (2007). The lowest plants densities were observed under the interhills intercropping system whatever the year. Cropping system had a high significant effect $(P<0.01)$ on cowpea grain yield (Figure $4(\mathrm{a}))$. The best grains yield was obtained under IT89KD-374 sole crop, followed by the CZ11-94-5C. The lowest yields were observed under the interhills cropping system.

3.1.5. Cropping System Effects on Millet Yields. Multiyear analysis of grain and above-ground total biomass dry yields of millet showed high significant interactions between year, cropping system, and cowpea variety $(P=0.003$ and $P=0.002$, resp.). The highest yields were obtained under cowpea-millet rotation (Figure $4(\mathrm{~b})$ ). The grain and the above-ground biomass total dry yields of CZ11-94-5C-millet rotation in the first year (2008) were at the top of the ranking.

\subsection{Experiment in Farmers' Fields}

3.2.1. Cropping System Effects on Cowpea Nodules Number and Weight. The differences between nodules numbers were highly significant $(P<0.01)$ in favor of CZ11-94-5C, whatever the cropping system (Table 2). No significant

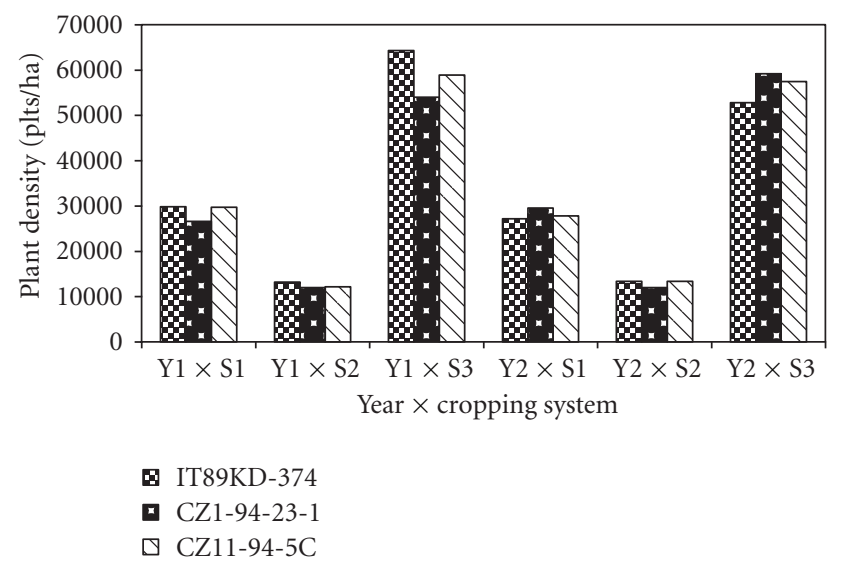

Figure 3: Cowpea plants density (plants/ha) as affected by year $\times$ cropping system $\times$ cowpea variety interactions effects $(P<0.01)$ at harvest at Cinzana Agronomic Research Station, 2007 and 2008. Y1: year 1 (2007); Y2: year 2 (2008), S1: Alternate rows intercropping (1 row millet/ 1 row cowpea), S2: Inter hills inter cropping (2 hills millet/1 hill cowpea), S3: Cowpea sole crop, Cowpea varieties: IT89KD-374, CZ1-94-23-1 and CZ11-94-5C.

difference was observed between the dry nodules weight $(P>$ $0.05)$.

3.2.2. Crops Yields. Cropping system had high significant effect $(P<0.01)$ on crops yields (Table 2$)$. The best cowpea 
TABLE 2: Cropping system effects on cowpea nodules number (nodules/plant), nodules dry weight (mg/plant) at bloom stage, and cowpea and millet grain yield ( $\mathrm{kg} / \mathrm{ha})$ in farmers' fields in 2010.

\begin{tabular}{|c|c|c|c|c|}
\hline Cropping systems & $\begin{array}{l}\text { Cowpea nodules } \\
\text { number by plant }\end{array}$ & $\begin{array}{c}\text { Cowpea nodules dry } \\
\text { weight (mg/plant) }\end{array}$ & $\begin{array}{l}\text { Cowpea grain } \\
\text { yield }(\mathrm{kg} / \mathrm{ha})\end{array}$ & $\begin{array}{l}\text { Millet grain } \\
\text { yield }(\mathrm{kg} / \mathrm{ha})\end{array}$ \\
\hline Farmers' control & No* & No* & No* & $465^{\mathrm{a}}$ \\
\hline Cowpea variety CZ11-94-5C sole crop & $22^{\mathrm{a}}$ & 160 & $730^{\mathrm{a}}$ & No* \\
\hline Cowpea variety IT89KD-374 sole crop & $16^{\mathrm{b}}$ & 117 & $605^{\mathrm{b}}$ & No* \\
\hline Millet/CZ11-94-5C alternate rows intercropping (1 row/1 row) & $20^{\mathrm{ab}}$ & 140 & $390^{c}$ & $335^{\mathrm{b}}$ \\
\hline Millet/IT89KD-374 alternate rows intercropping ( 1 row/ 1 row) & $15^{\mathrm{b}}$ & 119 & $340^{\mathrm{cd}}$ & $350^{\mathrm{b}}$ \\
\hline Millet/CZ11-94-5C alternate rows intercropping (2 rows/1 row ) & $23^{\mathrm{a}}$ & 163 & $280^{\mathrm{cd}}$ & $485^{\mathrm{a}}$ \\
\hline Millet/IT89KD-374 alternate rows intercropping (2 rows/1 row) & $17^{\mathrm{b}}$ & 139 & $245^{\mathrm{d}}$ & $495^{\mathrm{a}}$ \\
\hline Effect & $P$ value & $P$ value & $P$ value & $P$ value \\
\hline Cropping system & $<0.01$ & 0.09 & $<0.01$ & $<0.01$ \\
\hline Coefficient of variation (\%) & 37.02 & 45.21 & 42.17 & 21.41 \\
\hline
\end{tabular}

Means followed by the same letters in the same column are not significantly different $(P \leq 0.05)$, according to Duncan test.

No*: no millet.

grain yield was obtained under CZ11-94-5C sole crop. No significant yield differences were observed between intercropping systems. Millet grain yields were significantly higher $(P<0.01)$ for intercropping 2 rows of millet/1 row of cowpea. Whatever the crop, the results showed the importance of plants density in getting good grain yields.

\section{Discussion}

The results showed highly significant effects of cropping system on cowpea nodules number and nodules dry weight whatever the stage of observation with three-way high significant interaction of year, cropping system, and cowpea variety. These results were not supported by the finding of Kombiok et al. [12] who reported that cropping systems have no effects on nodule number and nodule weight. Low nodulation in interhills intercropping could be explained by the delay in the cowpea crop sowing in this system and shading effect which was much more important. Shading effect significantly inhibits the branching of cowpea when intercropped with the millet [13]. Interhills cropping limited the growth and development of the cowpea because of the competition between millet and cowpea for water, light, and soil nutrients, thereby reducing the nodulation. The performance of the CZ11-94-5C and the IT89KD-374 (Figure 2) was in agreement with Yusuf et al. [14] results. The integration of the CZ11-94-5C and the IT89KD-374 in cropping systems, because of the weight of their nodules, may have a positive effect on the biological nitrogen fixation in the producers' fields in the Sudano-Sahelian zone where continuous decline in the soil fertility and fertilizers accessibility are major constraints [15]. According to Graham et al. [16], the nodules weight is an important indicator for symbiotic potential evaluation.

The differences between cropping systems effects on cowpea nodulation can be explained by differences in plants density of the different systems. These results were consistent with those of Makoi et al. [7]. The varieties CZ11-94-5C and
IT89KD-374 had high nitrogen fixation potential (high nodulation) in sole and alternate rows cropping with the millet. In reference to the results of Moharram et al. [17], Bell et al. [18], according to which there is a relationship between nodulation and nitrogen fixation, those varieties will set more nitrogen in the system than CZ1-94-23-1. However, nodule number and weight may be affected by soil low content in available phosphorus (09 ppm). Compared to Russel [19] results, nodule number and weight may be affected by soil low content in available phosphorus (09 ppm). Phosphorus increases the nodulation and improves the symbiotic activity [20, 21]. Osunde et al. [22] Carsky [23] showed an increase in the number and weight of nodules per plant of cowpea with phosphorus application.

The results of the main parameters for symbiotic fixation (nodulation number and weight and the efficiency of nodules) showed that the variety CZ11-94-5C has the best symbiotic potential.

Mycorrhization rates increased from 45th day after emergence to the flowering, whatever the cropping system was in agreement with the observations of Bagayoko [24]. The effects of crop rotations on the colonization of the cereals roots by mycorrhizal fungi depend on the observation period. The best mycorrhization rates observed in 2009 compared to 2008 can be explained by the presence of more powerful strains and/or the precipitation factor. The ten-day repartitions of the rainfalls of the two years were significantly different, although the difference between the total for 2008 $(654 \mathrm{~mm})$ is not significantly different from that of 2009 (663 mm).

The best cowpea grains yields in sole crop (Figure 4(a)) with regard to intercropping were consistent with results of Ndakidemi and Dakora [25]. The yields advantage in cowpea sole crop was explained not only by the high plants density but also by the absence of competition with other crops. In intercropping system, photosynthesis reduction of legume can occur because of the shading effects of the leading cereal crop, resulting in low productivity of legumes. This confirmed the results of Makoi et al. [7]. 


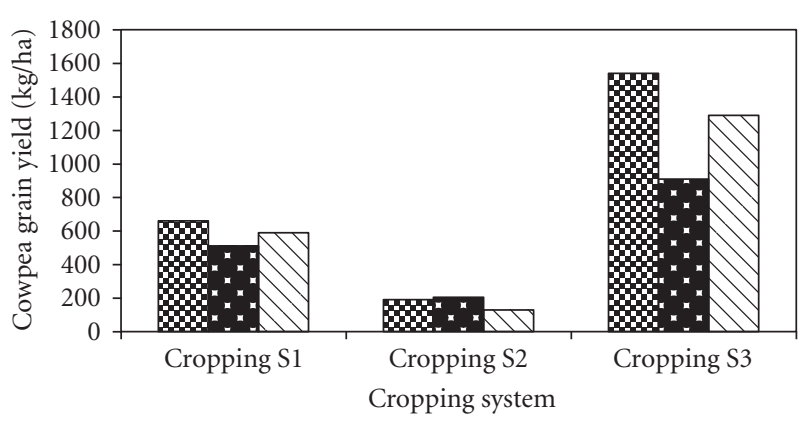

(a)

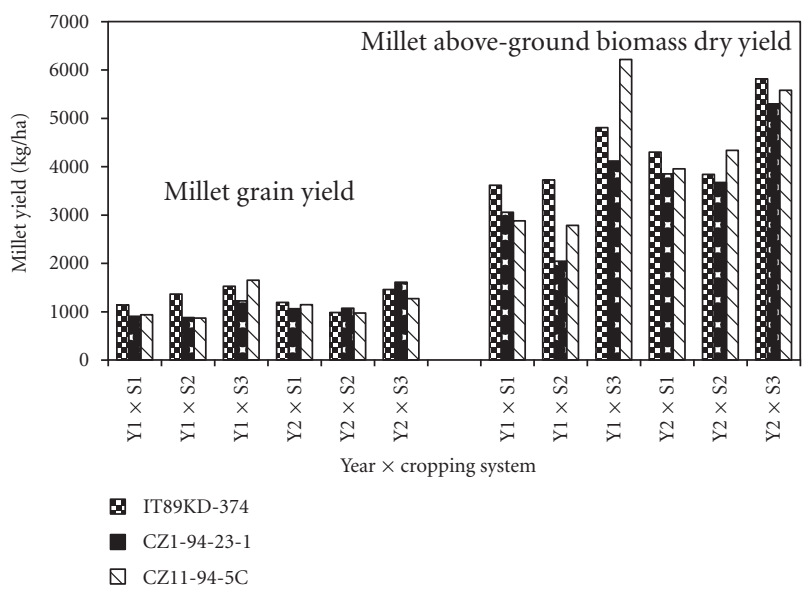

(b)

FIGURE 4: Crops yields: (a) cowpea grain as affected by cropping system $\times$ cowpea variety interactions effects $(P<0.01), 2007$ and 2008; (b) subsequent millet grain and above-gorund biomass dry yields as affected by year $\times$ cropping system $\times$ cowpea variety threeway interaction effects at Cinzana Agronomic Research Station, 2008 and 2009. Y1: year 1 (2008), Y2: year 2 (2009), S1: alternate rows intercropping (1 row millet/1 row cowpea), S2: interhills intercropping (2 hills millet/1 hill cowpea), S3: cowpea sole crop, cowpea varieties: IT89KD-374, CZ1-94-23-1, and CZ11-94-5C.

Under low plants density, cowpea roots accumulate more nutrients, including mineral $\mathrm{N}$, which inhibits the activity of nitrogenase $[26,27]$. Soil available phosphorus content in the first 20 centimeters $(09 \mathrm{ppm})$ is less than the defined standards for the achievement of the potential yield of legumes (25 to 30 ppm, Breman et al. [28]; 20-25 ppm, Russel [19]). Therefore, this low available phosphorus content would limit cowpea nodulation, plant development, and yield.

Increase in millet grains yield in rotation is consistent with the results obtained by different authors [3, 29, 30]. Results showed the importance of cowpea plants density in the previous crop on improvement of the performance of the subsequent millet yield. These results are consistent with those of Ayisi et al. [27] and Makoi et al. [7]. The great biomass produced under the high cowpea plants density was more likely to improve soil nitrogen fertility thereby increasing subsequent crops yields [7]. Pulses generally take more than half of their nitrogen requirements in the atmosphere [5]. Therefore, they take less nitrogen in the soil compared to the nonfixing plants (cereals). However, in the cereal/legume intercropping, cereal takes all of its nitrogen needs from soil reserves; therefore, fewer quantity of nitrogen will be saved for subsequent crop. Bationo et al. [31] recommended a more integrated nutrient management which includes crops rotation in the Sudano-Sahelian zone, where the climate and soil realities are negative factors limiting the productivity of soils. Rotation of crops increases the production of biomass and crop residue necessary to the improvement of the low level of soil organic matter. Figure 4(b) showed that cowpeamillet rotation in general and CZ11-94-5C-millet rotation in particular can potentially improve yield and production in the Sudano-Sahelian zone of Mali.

Rhizobium associated with cowpea in different cropping systems may also explain the results. Some specific strains associated with cowpea varieties in different cropping systems are responsible for the performance of crops rotation, especially that of CZ11-94-5C-millet. In biennial rotation (cowpea-millet), the best millet grain yields $(2100 \mathrm{~kg}$ and $2000 \mathrm{~kg} \mathrm{ha}^{-1}$ ) were observed after two previous cowpea with Bradyrhizobium strains that were different from those associated with two other varieties of cowpea with less important residual effects [32]. These Bradyrhizobium strains, despite their lower nodulation frequencies (4 to $16 \%$ of infected nodules), seemed to be effective in improving soil fertility by cowpea cropping for the subsequent millet crop. The compatibility of specific genetic groups with this variety can be more efficient. This is in accordance with the results obtained by N'diaye et al. [33] and Fall et al. [34].

The precipitation regime (year factor) also influenced grains and above-ground dry biomass yields, even though the annual rainfalls were equivalent $(654$ and $663 \mathrm{~mm}$, resp.). This was explained by the frequency and the ten-day rain quantities which were different during the two millet cropping years (2008 and 2009, Figure 1).

\section{Conclusion}

Results of this study showed the performance of cowpea CZ11-94-5C variety nodulation and its contribution to the improvement of the performance of the subsequent millet yield. The tested cowpea varieties and cropping systems did not have a significant influence on mycorrhizal colonization of millet and cowpea roots.

\section{Acknowledgments}

This research was supported by Syngenta Foundation for Sustainable Agriculture. The authors would like to thank Dr. Oumar NIANGADO, representing this Foundation in West Africa. Acknowledgment is also due to Mr. Oumar TOGOLA and Cheick A. KEITA for their assistance in field work; Drs. Drissa DIALLO, Sidy B. COULIBALY, and Minamba BAGAYOKO for reviewing the paper.

\section{References}

[1] Direction Nationale de la Statistique et de l'Informatique (DNSI), Cellule de Planification et de Statistique (CPS), and Direction Nationale de l'Appui au Monde Rural (DNAMR), 
"Enquête agricole de conjoncture. Résultats définitifs des campagnes 2003 et 2004," p. 115, 2005.

[2] N. Sanginga, O. Lyasse, and B. B. Singh, "Phosphorus use efficiency and nitrogen balance of cowpea breeding lines in a low $\mathrm{P}$ soil of the derived savanna zone in West Africa," Plant and Soil, vol. 220, no. 1-2, pp. 119-128, 2000.

[3] B. V. Bado, ,Rôle des légumineuses sur la fertilité des sols ferrugineux tropicaux des zones guinéenne et soudanienne du Burkina Faso [Ph.D. Thèse], Faculté des études supérieures, Université Laval, Québec, Canada, 2002.

[4] A. R. J. Eaglesham, M. D. Stowers, M. L. Maina, B. J. Goldman, M. J. Sinclair, and A. Ayanaba, "Physiological and biochemical aspects of diversity of Bradyrhizobium sp. (Vigna) from three West African soils," Soil Biology and Biochemistry, vol. 19, no. 5, pp. 575-581, 1987.

[5] M. B. Peoples, D. F. Herridge, and J. K. Ladha, "Biological nitrogen fixation: an efficient source of nitrogen for sustainable agricultural production?" Plant and Soil, vol. 174, no. 1-2, pp. 3-28, 1995.

[6] F. D. Dakora and S. O. Keya, "Contribution of legume nitrogen fixation to sustainable agriculture in Sub-Saharan Africa," Soil Biology and Biochemistry, vol. 29, no. 5-6, pp. 809-817, 1997.

[7] J. H. J. R. Makoi, S. B. M. Chimphango, and F. D. Dakora, "Effect of legume plant density and mixed culture on symbiotic $\mathrm{N}_{2}$ fixation in five cowpea (Vigna unguiculata L. Walp.) genotypes in South Africa," Symbiosis, vol. 48, no. 1-3, pp. 5767, 2009.

[8] B. Venkateswarlu, K. Hari, and J. C. Katyal, "Influence of soil and crop factors on the native rhizobial populations in soils under dryland farming," Applied Soil Ecology, vol. 7, no. 1, pp. 1-10, 1997.

[9] CPCS, Comité Pédologique pour la Classification des sols, 1969.

[10] B. Kéita, L. Dioni, and D. Diallo, Etude Pédologique de la Station de Recherche Agronomique de Cinzana, Institut d'Economie Rurale (IER), 1982.

[11] J. M. Phillips and D. S. Hayman, "Improved procedures for cleaning roots and staining parasitic and vesicular-arbuscular mycorrhizal fungi for rapid assessment of infection," Transactions of the British Mycological Society, vol. 55, no. 1, pp. 158$161,1970$.

[12] J. M. Kombiok, E. Y. Safo, and C. Quansah, "Yield and nitrogen fixation of cowpea as affected by tillage and cropping systems in the Northern Savanna Zone of Ghana," West African Journal of Applied Ecology, vol. 7, 2005.

[13] A. E. Hall and P. N. Patel, "Cowpea improvement for semiarid regions of sub-Sahara Africa," in Food Grain Production in Semi-Arid Africa, J. M. Menyonga, T. Bezuneh, and A. Youdeowei, Eds., pp. 279-290, OAU/STRC-SAFGRAD, SemiArid Food Grain Research and Development, Ouagadougou, Burkina Faso, 1987.

[14] A. A. Yusuf, R. C. Abaidoo, E. N. O. Iwuafor, and O. O. Olufajo, "Genotype effects of cowpea and soybean on nodulation, $\mathrm{N}_{2}$ fixation and $\mathrm{N}$ balance in the Northern Guinea savanna of Nigeria," Journal of Agronomy, vol. 7, no. 3, pp. 258-264, 2008.

[15] D. Diallo, B. B. Zorome, A. Maiga, A. Diouf, A. Ka, and E. D. Dapola, Evolution de l'agriculture pluviale dans un contexte de variabilité climatique en zone soudano-sahélienne d'Afrique de l'Ouest, Cahiers Agricultures, 2010.

[16] P. H. Graham, M. Hungria, and B. Tlusty, "Breeding for better nitrogen fixation in grain legumes: where do the rhizobia fit in?" Crop Management, 2004.

[17] T. M. M. Moharram, M. S. A. Safwat, F. S. Faris, and T. H. El-Dahtory, "Response of some pea cultivars to phosphorus fertilization using N15 methodology," in Recent Developments in Biological Nitrogen Fixation Research in Africa. Proceedings of the 5th International Conference of the African Association for Biological Nitrogen Fixation (AABNF), pp. 301-308, Hassan II Institute of Agronomy and Veterinary Medicine (IAV), Rabat, Morocco, September 1992.

[18] M. J. Bell, G. C. Wright, Suryantini, and M. B. Peoples, "The N2-fixing capacity of peanut cultivars with differing assimilate partitioning characteristics," Australian Journal of Agricultural Research, vol. 45, no. 7, pp. 1455-1468, 1994.

[19] J. S. Russel, "Soil factors affecting the growth of legumes on low fertility soils in the tropics and sub-tropics," in Mineral Nutrition of Legumes in Tropical and Subtropical Soils, C. S. Andre and E. J. Kramprath, Eds., pp. 75-92, CSIRO, Australia, 1978.

[20] J. A. Olofintoye, "Cowpea (Vigna unguiculata L. Walp) response to different levels of phosphorous and nitrogen in the Guinea Savanna of Nigeria," Philippine Agriculturalist, vol. 69, no. 3, pp. 411-418, 1986.

[21] K. E. Giller and K. J. Wilson, Nitrogen Fixation in Tropical Cropping Systems, C.A.B. International, Wallingford, UK, 1995.

[22] A. O. Osunde, A. Bala, and A. Uzoma, "Differential responses of Cowpea Breeding lines to Phosphorus and Rhizobial Inoculation in a Low Phosphorus Soil in the Nigerian Southern Guinea Savana," in Enhancing BNF Research and Application for Food Security and Poverty Alleviation in Smallholder African farming Communities. Conference Proceedings of the African Association for Biological Nitrogen-Fixation (AABNF), R. C. Abaidoo and S. K. A. Danso, Eds., 2002.

[23] R. J. Carsky, "Amélioration de la gestion des sols par l'introduction de légumineuses dans les systèmes céréaliers des savanes africaines," Cahiers Agricultures, vol. 12, pp. 227-233, 2003.

[24] M. Bagayoko, Site-specific effects of cereal/legume rotation in West Africa: soil mineral nitrogen, mycorrhizae and nematodes [Ph.D. Thèse], Université Honheim, Allemagne, 1999.

[25] P. A. Ndakidemi and F. D. Dakora, "Yield components of nodulated cowpea (Vigna unguiculata) and maize (Zea mays) plants grown with exogenous phosphorus in different cropping systems," Australian Journal of Experimental Agriculture, vol. 47 , no. 5, pp. 583-589, 2007.

[26] J. Streeter, "Inhibition of legume nodule formation and $\mathrm{N}_{2}$ fixation by nitrate," CRC Critical Review Plant Science, vol. 7, no. 1, pp. 1-23, 1988.

[27] K. K. Ayisi, R. J. Nkgapele, and F. D. Dakora, "Nodule formation and function in six varieties of cowpea (Vigna unguiculata L. Walp.) grown in a nitrogen-rich field soil in South Africa," Symbiosis, vol. 28, no. 1, pp. 17-31, 2000.

[28] H. Breman, D. Coulibaly, and Y. Coulibaly, Amélioration de parcours et production animale; le rôle des légumineuses en Afrique de l'Ouest, vol. 17 of Rapports PSS, IER, Bamako, Mali, DAN-UAW, Wageningen, The Netherlands; AB-DLO, Wageningen, The Netherlands, 1996.

[29] S. P. Wani, O. P. Rupela, and K. K. Lee, "Sustainable agriculture in the semi-arid tropics through biological nitrogen fixation in grain legumes," Plant and Soil, vol. 174, no. 1-2, pp. 29-49, 1995.

[30] A. Bationo and B. R. Ntare, "Rotation and nitrogen fertilizer effects on pearl millet, cowpea and groundnut yield and soil chemical properties in a sandy soil in the semi-arid tropics, West Africa," Journal of Agricultural Science, vol. 134, no. 3, pp. 277-284, 2000.

[31] A. Bationo, M. V. K. Sivakumar, K. Acheampong, and K. Harmsen, "Technologies pour combattre la dégradation 
des terres dans la région soudano-sahélienne d'Afrique de l'Ouest," in Lutte contre la dégradation des sols en Afrique au sud du Sahara: comptes rendus de l'Atelier international planification pours l'Action dans les zones limitrophes du désert, M. V. K. Sivakumar and J. B. Wills, Eds., Institut international de recherche sur les cultures des zones tropicales semi-arides, Andhra Pradesh, India, 1995.

[32] Z. Kouyaté, Amélioration de la fertilité du sol et du rendement des cultures en zone soudano-sahélienne du Mali : rôle du mode de gestion des légumineuses fixatrices d'azote, des résidus de récolte et $d u$ phosphate naturel $d u$ Tilemsi [Thèse Unique], U.F.R. des Sciences de la Terre et des Ressources Minières; Université de Cocody, Abidjan, Côte d'Ivoire, 2006.

[33] M. A. F. N'diaye, M. M. Spencer, and M. Gueye, "Genetic variability in dinitrogen fixation between cowpea [Vigna unguiculata (L.) Walp] cultivars determined using the nitrogen-15 isotope dilution technique," Biology and Fertility of Soils, vol. 32, no. 4, pp. 318-320, 2000.

[34] L. Fall, D. Diouf, M. A. Fall-Ndiaye, F. A. Badiane, and M. Gueye, "Genetic diversity in cowpea [Vigna unguiculata (L.) Walp.] varieties determined by ARA and RAPD techniques," African Journal of Biotechnology, vol. 2, no. 2, pp. 48-50, 2003. 


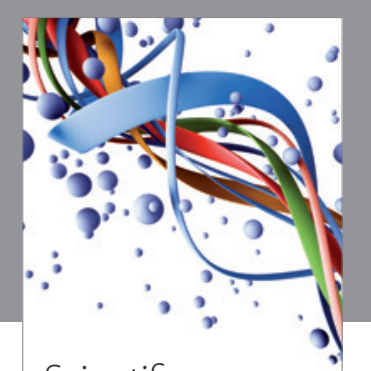

Scientifica
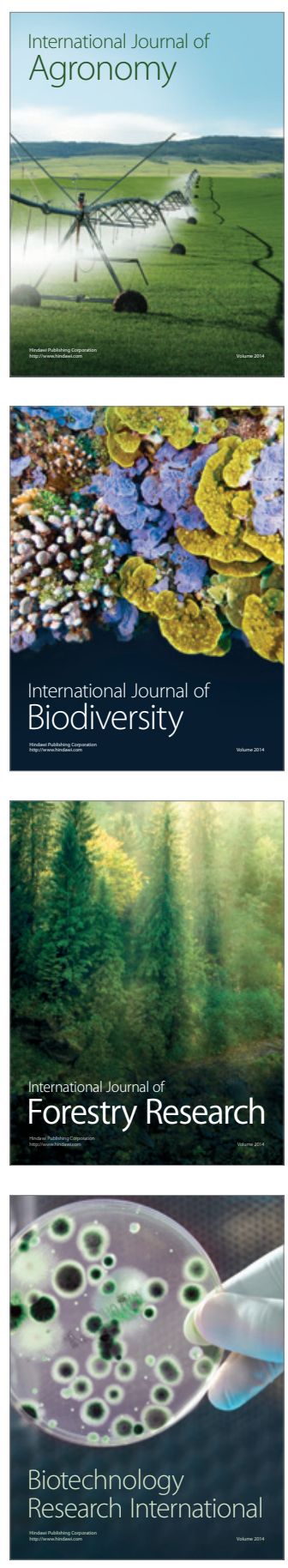
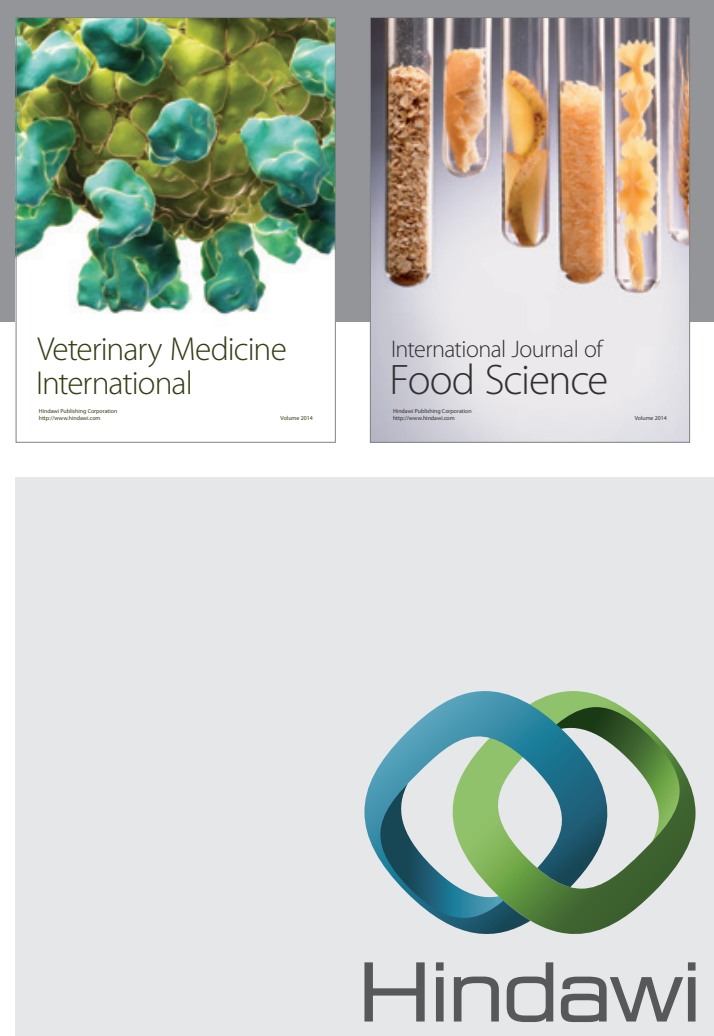

Submit your manuscripts at

http://www.hindawi.com
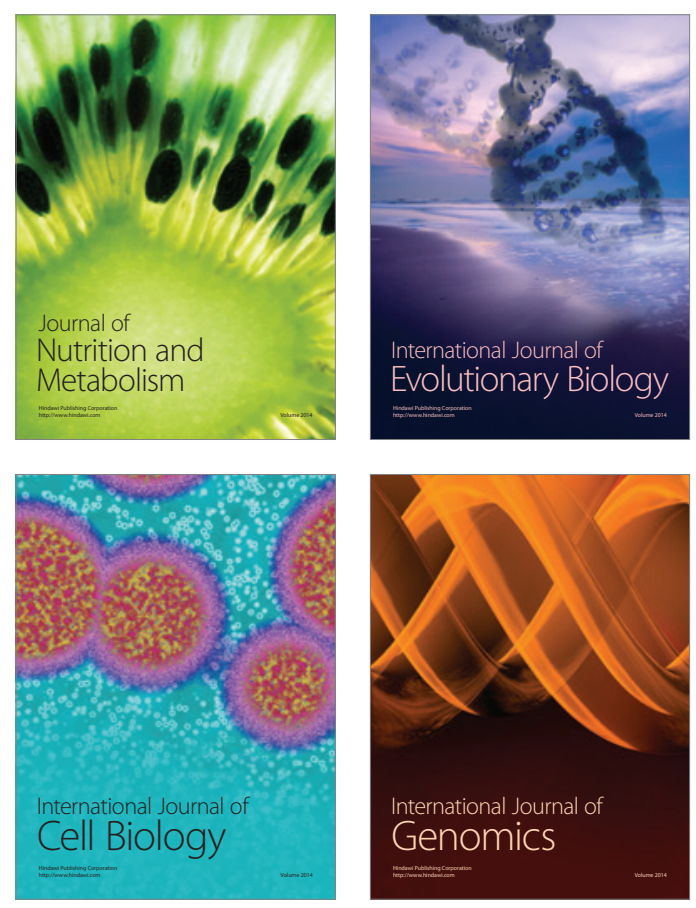
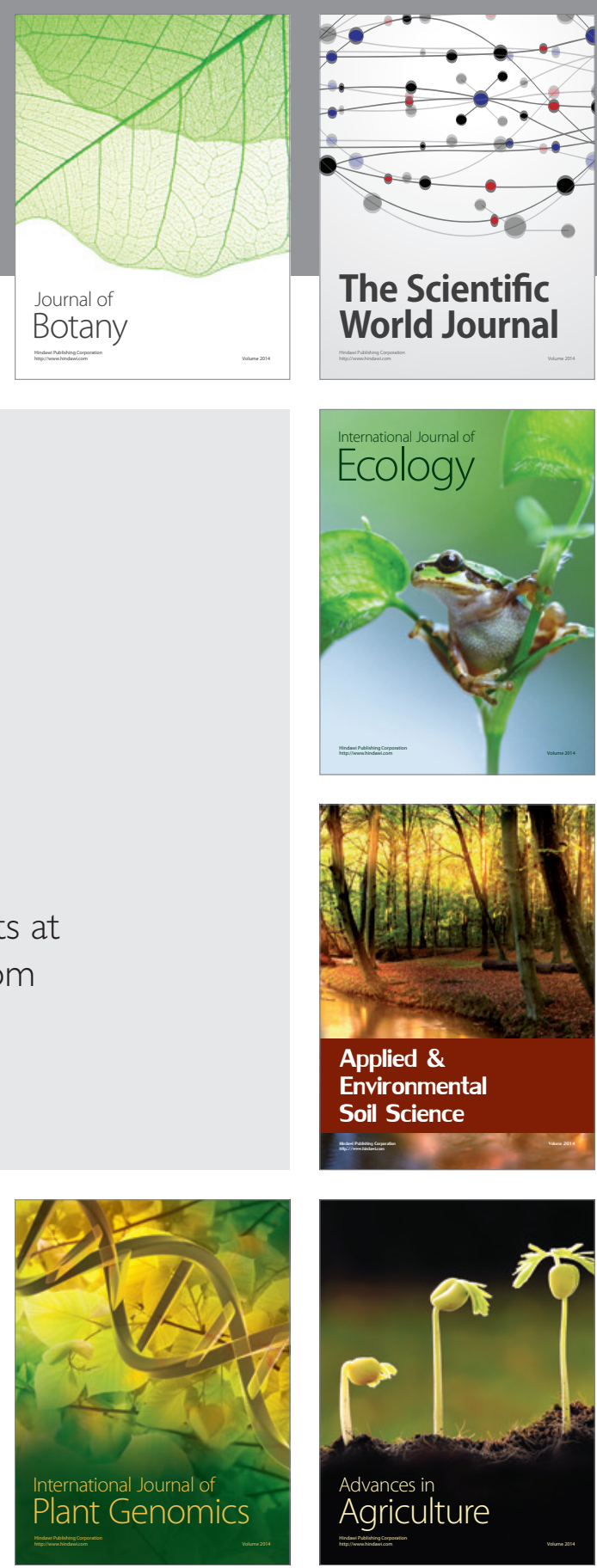

The Scientific World Journal
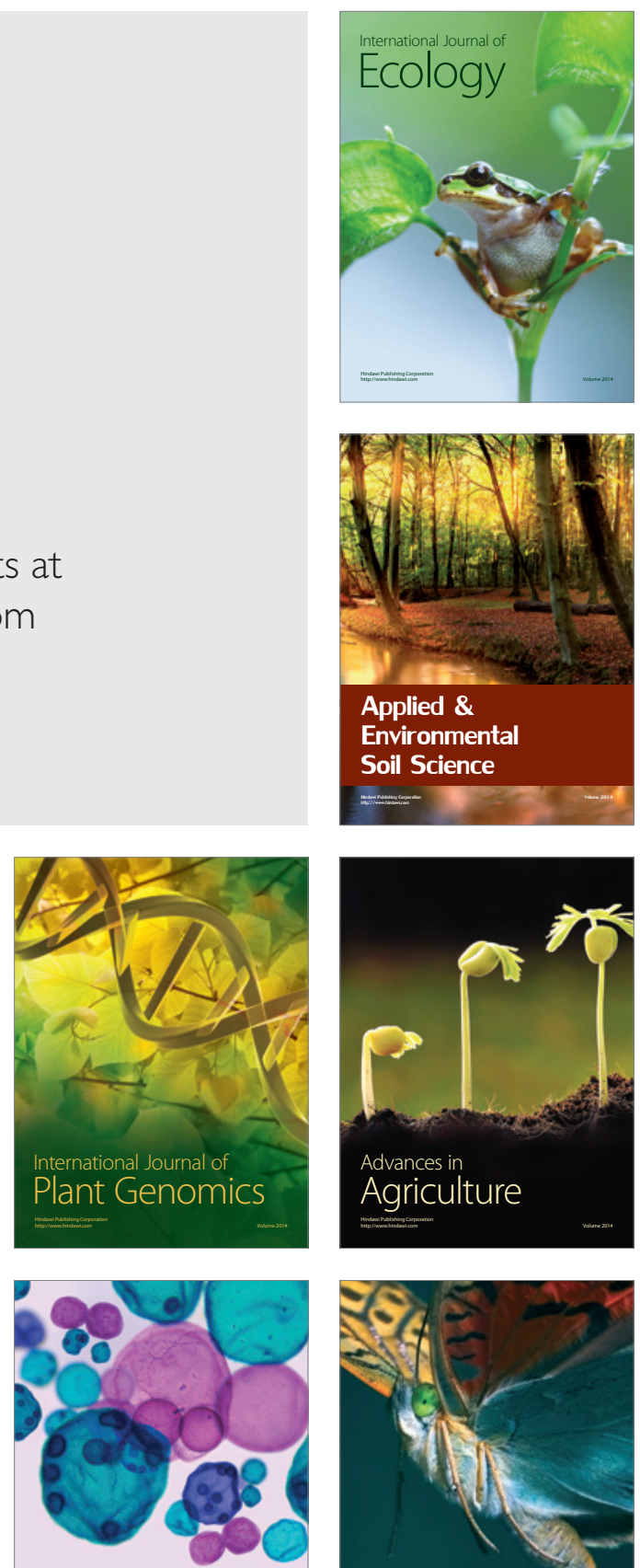

International Journal of Microbiology

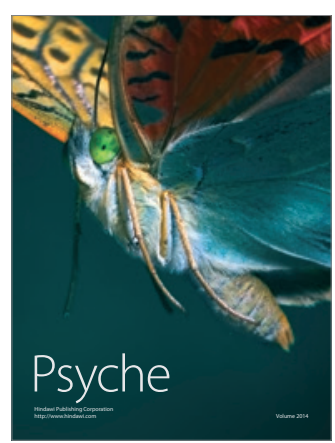

